Article

\title{
Living with COVID-19 and Sustaining a Tourism Recovery-Adopting a Front-Line Collaborative Response between the Tourism Industry and Community Pharmacists
}

\author{
Glenn McCartney ${ }^{1, *(D)}$, Carolina Oi Lam Ung ${ }^{2}$ and José Ferreira Pinto ${ }^{1}$ \\ 1 Faculty of Business Administration, University of Macau, Macau, China; yb87008@umac.mo \\ 2 State Key Laboratory of Quality Research in Chinese Medicine, Institute of Chinese Medical Sciences, \\ Department of Public Health and Medicinal Administration, Faculty of Health Sciences, University of Macau, \\ Macau, China; carolinaung@um.edu.mo \\ * Correspondence: glennm@um.edu.mo
}

check for

updates

Citation: McCartney, G.; Ung, C.O.L.; Pinto, J.F. Living with COVID-19 and Sustaining a Tourism Recovery -Adopting a Front-Line Collaborative Response between the Tourism Industry and Community Pharmacists. Tour. Hosp. 2022, 3 , 47-68. https://doi.org/10.3390/ tourhosp3010004

Academic Editor: Brian Garrod

Received: 16 December 2021

Accepted: 12 January 2022

Published: 14 January 2022

Publisher's Note: MDPI stays neutral with regard to jurisdictional claims in published maps and institutional affiliations.

Copyright: (C) 2022 by the authors. Licensee MDPI, Basel, Switzerland. This article is an open access article distributed under the terms and conditions of the Creative Commons Attribution (CC BY) license (https:// creativecommons.org/licenses/by/ $4.0 /$ )

\begin{abstract}
While the COVID-19 pandemic evolves and new variants emerge, destinations and cities look to tourism recovery, cautiously rebooting and re-opening borders. Since the start of the pandemic, dramatic lockdowns have been employed, resulting in dire economic and social consequences to the tourism and hospitality industry and creating the need for a more feasible and sustainable response in the post-pandemic era. Pandemic vigilance and resilience at the societal level have become key in pandemic preparedness. However, due to the complexity of managing COVID-19, no clear cross-disciplinary collaborative framework for tourism recovery has been developed. Cross-sector collaboration to collectively integrate resources, capabilities, and experiences should be prioritised to spearhead tourism recovery plans. With insight on public health, pandemic preparedness, and community access, we hypothesised that cross-industry collaboration between the tourism industry and the pharmacist profession is relevant to the measures adopted for recovery from the COVID-19 pandemic. To examine this hypothesis, this study aimed to explore perceptions from key stakeholders in the tourism and the pharmacist sectors on cross-industry collaboration towards COVID-19 management and the "know-how" in developing, adopting, and advancing such a partnership. This exploratory study adopts and advances the 'Four Cs' conceptual framework of communication, cooperation, coordination, and collaboration. In terms of our hypothesis, interview responses with tourism executives and CPs confirm the framework's suitability and the importance of an interdisciplinary collaborative approach between CPs and the tourism sector to craft a sustainable pathway to recovery from COVID-19 and future pandemic measures as borders re-open and international mobility increases. A tourism recovery strategy from this pandemic can occur more judiciously through a collaborative partnership with an extensive network of pharmacists within communities and popular tourism sites, as CPs have valuable healthcare resources and the ability to track and communicate healthcare alerts to tourism destination recovery efforts.
\end{abstract}

Keywords: COVID-19; pandemic; lockdown; collaboration; community pharmacist; tourism; recovery

\section{Introduction}

The COVID-19 pandemic has severely impacted the tourism industry, with the outlook remaining highly uncertain and complicated due to the challenges of managing the pandemic globally. Misclassifying COVID-19, particularly in the western hemisphere, to consider the virus a maximum risk led to poor pandemic management [1]. Limited preparedness, knowledge, and experience on how to act in the pandemic have left the industry vulnerable and exposed to consequences that quickly occurred as the pandemic struck [2].

With the risk and uncertainty of the pandemic, attempts to re-open borders have been met with sudden lockdowns and mobility restrictions as virus cases surged again [3-6]. 
The impacts of COVID-19 go beyond economic terms, affecting the psychological wellbeing of COVID-19 patients, front-line personnel, and those in lockdown [7]. Despite the ongoing presence of COVID-19, the pandemic's crippling economic impact on the travel and tourism industry across destinations has meant governments push ahead with re-opening agendas. This has included increasing speculation on the future outlook of tourism, and how and what tourism recovery will transform into, in various destinations [8]. Continued lockdowns could ultimately devastate the travel and tourism sector [9]. However, the reactivation of travel restrictions and destination lockdowns as new virus variants emerge, such as Delta and Omicron, reveals the challenge of exiting this loop.

While some recent literature has raised COVID-19 interventions to aid tourism recovery, such as the concept of vaccination travel [10,11], COVID-19 nucleic acid amplification tests (NAAT), and health code apps [12], given the potential millions on the move again and the need to sustain tourism recovery (i.e., avoiding a return to lockdowns), travel and tourism literature is largely silent on the 'how to' of this question. Removing travel restrictions has shown the importance of frequently testing visitors and the community receiving vaccines and subsequent booster vaccines, as well as being contact traced should a traveller become infected. One of the few acknowledgements in the tourism literature regarding the importance of interdisciplinary research between the medical sector and tourism and hospitality to aid destination recovery during COVID-19 states that:

“( ... ) no work in the tourism literature appears to have integrated a medical or health sciences perspective to reveal theoretical and practical insight for the tourism and hospitality industry. Interdisciplinary research is thus strongly encouraged in this vein, particularly with regard to the current pandemic." Wen et al. (2021, p. 312)

Previous COVID-19 tourism literature, to the extent of our knowledge, has not taken an interdisciplinary approach to develop a sustainable tourism model of collaboration, essentially ignoring the crucial interaction needed between tourism and healthcare professionals to battle and manage COVID-19, through which a sustainable pathway to tourism recovery might be possible. Scant observational data are available to test the hypothesis that cross-industry collaboration between the tourism industry and the pharmacist profession is relevant to the measures adopted for the recovery from the COVID-19 pandemic. Therefore, little is known about how to initiate, develop, adopt, and advance such collaborative efforts. Virus infections continue and new variants emerge, with authorities tasked with imposing travel mandates and mobility restrictions to contain. Nevertheless, there has been a call by health professionals for multidisciplinary research to respond to the COVID-19 pandemic [13-17].

To examine this hypothesis, this study aimed to explore perceptions from key stakeholders in the tourism and pharmacist sectors regarding cross-industry collaboration towards COVID-19 management and the "know-how" in developing, adopting, and advancing such a partnership. Our goals are, therefore, four-fold. First, we address this gap in the tourism recovery literature by developing, for the first time, an interdisciplinary collaboration framework between the tourism and pharmacy sectors to facilitate robust exchanges through cooperation, communication, and coordination. Second, we advance the tourism collaboration literature by embedding CPs (i.e., public health sector) as key stakeholders to advance tourism recovery during COVID-19. The pharmaceutical literature has provided COVID-19 exit strategy scenarios [18-20]; hence, tourism recovery studies need to align with health research advice on the virus. Third, through interviews with principal figures of the $\mathrm{CPs}$ and tourism sectors, we present practical steps and recommendations for tourism recovery using the conceptual model. Fourth, our findings indicate that the collaborative responses of coordination, communication, and cooperation from CPs and tourism professionals could provide a workable framework to chart a tourism recovery. 


\section{Background and the Macao Context}

\subsection{COVID-19 Containment, Travel Corridor, and Tourism Revival in Macao}

Macao confirmed its first case of COVID-19 on 22 January 2020. With rising COVID-19 cases, the city established a lockdown, closing its borders, with mandatory quarantine procedures put in place [21]. There were only 11,000 visitors to the city by April, a drop of $99.7 \%$ compared to April 2019, with 3.4 million visitors. A travel corridor enacted with China in September 2020 accounts for over $90 \%$ of total visitation to Macao [22]. The travel corridor means quarantine-free travel to and from Macao, although strict COVID-19 testing is required. Any others allowed to enter Macao, such as returning Macao residents or those from neighbouring Hong Kong, must isolate in designated quarantine hotels [23].

In 2019, travel and tourism contributed 50.3\% to Macao's GDP [24]. This economic dependency on tourism and casino revenues means that it is crucial that Macao recovers its industry sector quickly. Both China and Macao take a zero-tolerance position to COVID19. Therefore, as some COVID-19 cases emerged and were later eliminated in Macao in August and September 2021, this temporarily caused the reintroduction of travel restrictions between China and Macao, with targeted lockdowns in parts of the city, creating immediate falls in visitation, as evident in Figure 1 [22]. While Macao climbed to 724,342 visitor arrivals from mainland China in July, this dropped to 369,467 visitors when COVID-19 cases emerged in the city.

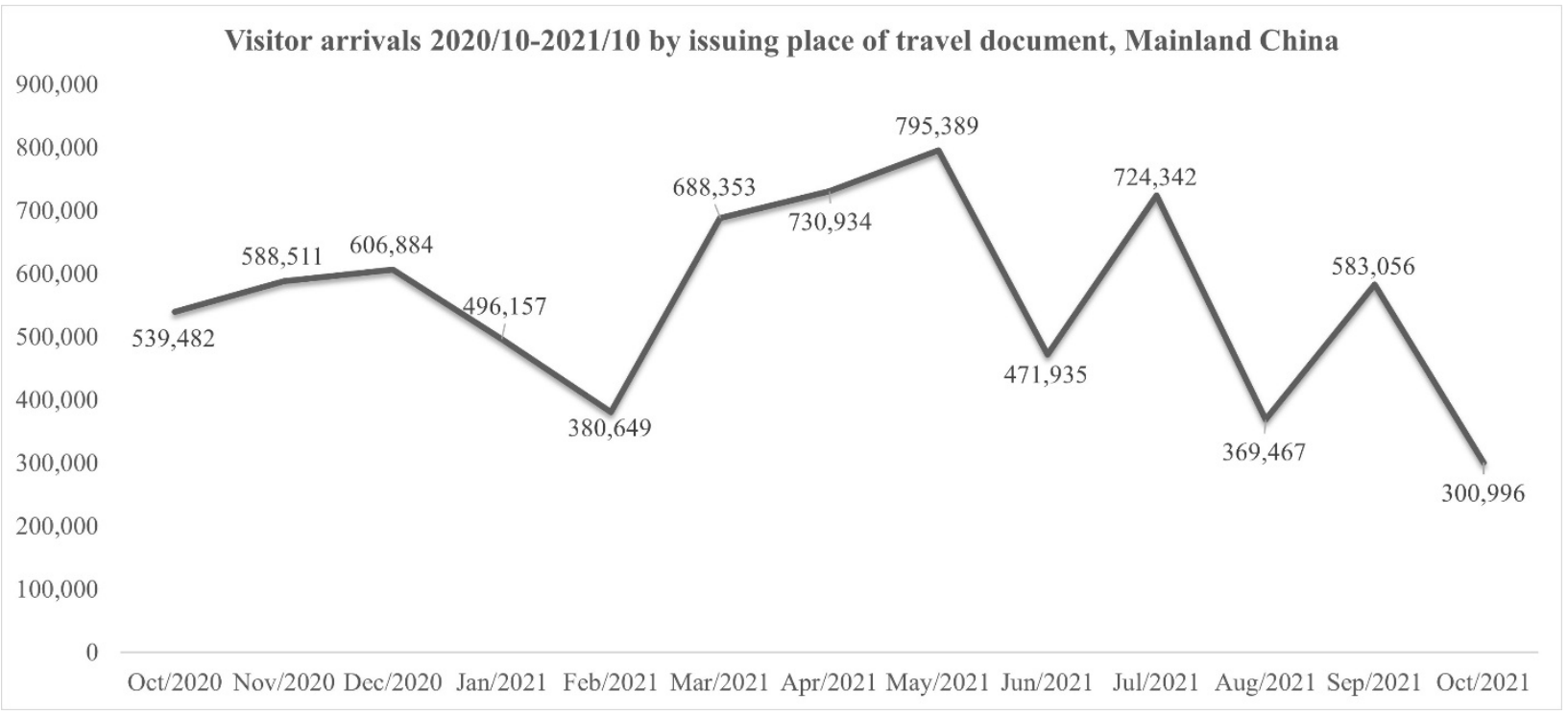

Figure 1. Tourism arrivals to Macao from mainland China.

Medical vigilance and strict mandates against the pandemic have been crucial to Macao's tourism re-opening success [21]. Macao is one of the most densely populated cities globally. Over 680,000 people reside within an area of $32.9 \mathrm{~km}^{2}$ [22], so rapid virus detection, management, and elimination are crucial. While our study was conducted in Macao, the implications of our collaborative study between CPs and tourism is especially relevant for tourism cities globally that are looking to reactivate high volumes of visitation.

\subsection{The Role of CPs during the Pandemic in Macao}

By 2020, Macao had 368 CPs who worked at 296 community pharmacies [25]. Figure 2 shows how CPs (represented by red dots) are located at Macao's borders and popular tourism and casino zones. Macao's CPs serve both residents and tourists, with visitors from mainland China using their visit to purchase foreign pharmaceutical and health-related products with a higher level of trust [26]. As such, serving tourists is familiar for both the $\mathrm{CPs}$ and the tourism sector. 


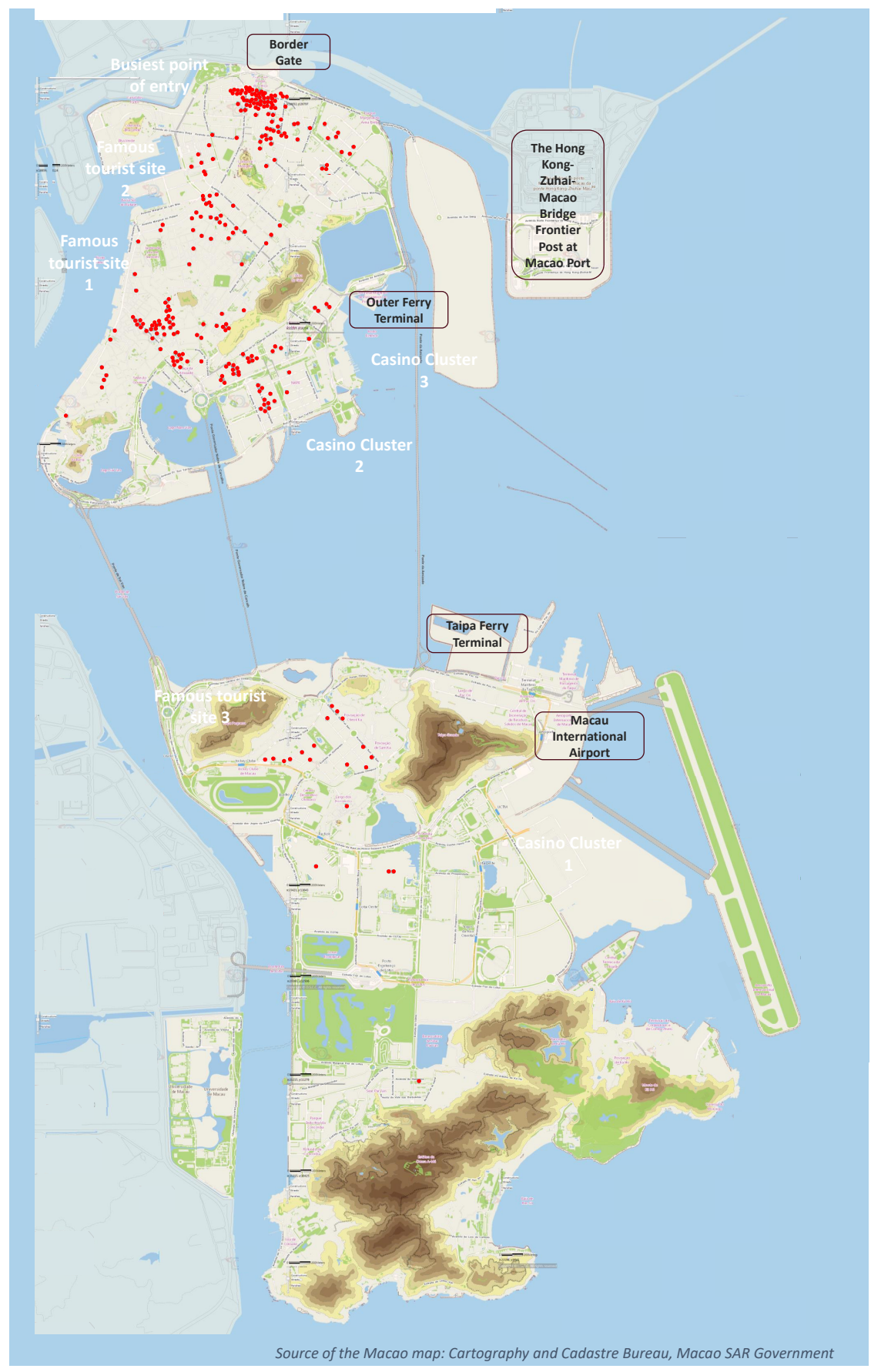

Figure 2. Distribution of community pharmacies in Macao. Map key (Map source, [27] Macao Cartography and Cadastre Bureau, 2020); casino cluster 1-includes Lisboa, Grand Lisboa, MGM, Wynn, Starworld, and L'Arc casino properties; casino cluster 2-the Cotai Strip, which includes Galaxy, Venetian Resort, Sands Cotai Central, Parisian, Studio City, City of Dreams, MGM, Cotai, Wynn Palace, and Grand Lisboa Palace integrated resort properties; casino cluster 3-includes Sands, Waldo, Rio, Landmark, Babylon, and Oceanus casinos; Border Gate-20.9 million visitors walked across in 2019 (Macao Government Statistics and Census Service, 2020); famous tourist site 1-'Historic Centre of Macau' includes San Ma Lo street (high street), Senado (city) square, town hall, Ruins of St. Paul, Sé Cathedral, Holy House of Mercy, and St. Dominic's church; famous tourist site 2-includes Red Market, Kun Iam Tong temple, 3-Lamps District, and Mong-Ha hill; famous tourist site 3-includes Taipa old village, Taipa House Museum, Pak Tai temple, and Our Lady of Carmo Church. 
Community pharmacies in Macao have performed a vital role in preventing the virus's spread by ensuring the availability of facemasks for the entire population. Through an ongoing public-private partnership, authorities designated 56 of Macao's 296 community pharmacies to dispense a guaranteed regular distribution of masks to Macao residents and migrant workers [20]. Since February 2020, masks must be worn in Macao's public and hospitality venues, including hotels, restaurants, bars, gyms, saunas, and casinos [25]. Given the lessons of mask wearing during the SARS outbreak in neighbouring Hong Kong in 2003, as well as the WHO's recommendations, mask wearing combined with other hygiene measures was recommended for preventing the spread of COVID-19 [20]. At a cost to the public of USD 1 for ten masks, by mid-2020, CPs had distributed over 200 million government-issued masks to the entire population through a centralised computer system [28].

\section{Literature Review}

\subsection{The Relevance of Cross-Disciplinary Research during COVID-19}

Interdisciplinary research refers to an active partnership involving two or more disciplines going beyond their disciplinary boundaries and working together to provide different perspectives on real-world, complex problems [29], and where multiple skillsets can develop scientific situational awareness capacity [30]. An earlier systematic literature review on COVID-19 research in tourism and hospitality showed half of the current studies were theoretical, investigating themes such as impacts, psychological effects, sustainability, and creating resilience [31]. The researchers concluded a lack of translational engagement, raising concerns about the limited practical innovations within COVID-19 research to advance tourism studies. Notable disaster research literature increasingly adopts interdisciplinary research [32]. To illustrate this, a thematic review of COVID-19 tourism and hospitality literature on reviving the tourism sector shows little reference to destination preparedness for the next pandemic following COVID-19 [33]. This point is noteworthy of highlighting. Despite calls after the severe acute respiratory syndrome (SARS) coronavirus crisis in 2003 for the tourism and hospitality industry to prevent and prepare for another fallout from a future health-related crisis [30], the COVID-19 pandemic has still had the most devastating impact on a largely ill-equipped tourism and hospitality industry. A case in point is the Spanish region of Sierra de Gata, where public and private collaboration was shown to have been a crucial factor to tackle and recover from COVID-19 and to be an exemplary lesson on a sustainable model of governance [34]. While warned, Spain ignored the possibility of a contagious virus and was severely impacted by COVID-19 when it first emerged [34].

In justifying the crucial importance of interdisciplinary research in disaster research, Peek and Guikema (2021) point out that disasters and hazards unfold on different geographic and temporal scales and occur at the intersection of national and built environments' social-technical systems. COVID-19 is a public health crisis that has become an economic crisis as the disease spreads, forcing the closure of hotels, restaurants, shops, and other related services [35]. Therefore, a sustainable model of tourism recovery must involve public health collaborations, and in our case, the work of CPs.

\subsection{Development of the Theoretical Framework}

Cross-sector collaboration seeks partnerships involving actors from different sectors to join forces to create synergy to address common challenges more effectively. Bedwell et al. p.130 [36] defined collaboration as 'an evolving process whereby two or more social entities actively and reciprocally engage in joint activities aimed at achieving at least one shared goal'. The literature finds that communication, coordination, cooperation, and collaboration are crucial inter-organisational partnering activities during a disaster; some crisis studies address more than one dimension [37] to increase collaborative decision making during a given disaster [38]. However, aligning different backgrounds, values, 
ideas and resources to make the best of capabilities and avoid conflicts across various sectors is highly challenging [39].

Our conceptual collaborative framework illustrated in Figure 3, adopted from [40], details three collaborative dimensions of coordination, cooperation, and communication. Communication provides the means to share information and interpret information to gain a shared understanding of complex situations and assess the consequences of possible joint measures [41,42]. Coordinating resource pools and managing available resources, synchronising tasks, and aligning activities all aim to support cross-sector activities and optimise productivity [43]. Cooperation relates to the stakeholders who recognise the importance of the overall goal and cross-functional activities, and those who consequently work together in an orchestrated manner in order to increase overall productivity [44]. We characterise context in this framework as a destination's attempts to manage the pandemic to assist tourism recovery while the pandemic persists and virus epidemiology evolves.

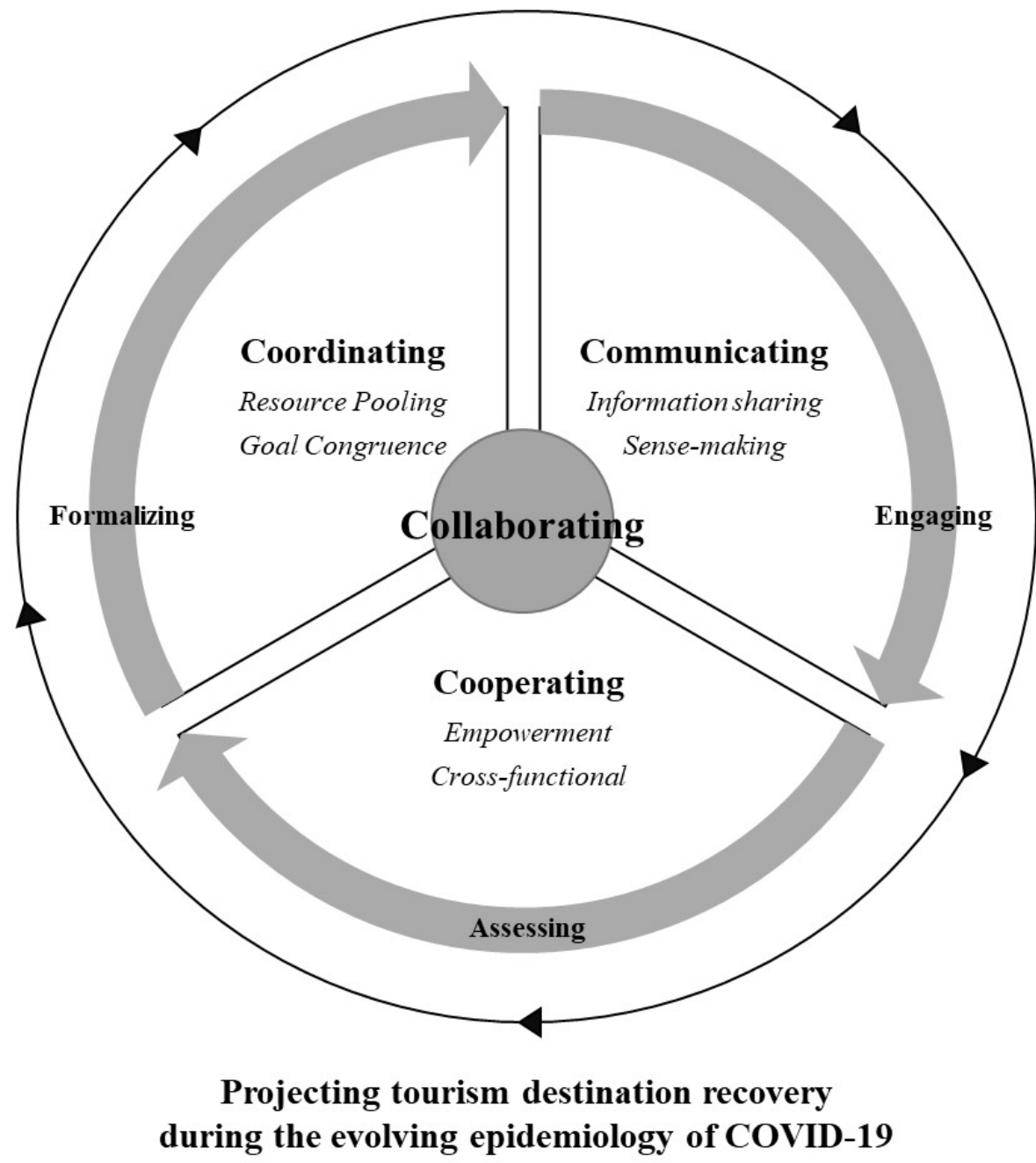

Figure 3. Framework for collaborative practice for tourism destination recovery (adapted from [40] Schuh et al., 2014).

\subsection{CPs and Tourism Collaboration}

Research has shown that providing high-quality public health services during COVID19 is pivotal in restoring traveller trust, confidence, and loyalty to tourism destinations [45]. Considering CPs' well-documented contributions to the overall management of COVID19 at the community level, including providing essential COVID-19 control measures, such as vaccination [46,47], they are viewed as a critical stakeholder in health care, and thus a crucial interface between tourists and the countermeasures against new COVID 
variants and future epidemics and pandemics. As such, in our study, we further explore the collaboration between the tourism industry and CPs as part of COVID-19 recovery.

CPs have already been embedded as strategic partners to combat the COVID-19 pandemic in the USA, where the CDC (Centers for Disease Control) have authorised CPs to be COVID-19 vaccination providers and centres. Through this collaboration and taking advantage of their widespread distribution, $\mathrm{CPs}$ reach across communities, including those in remote locations, to deliver healthcare supplies. CP participation reduces the burden on hospitals' essential services [48]. Involving CPs in public health measures is not new. The USA's pharmacists already have a crucial role in administering the annual influenza vaccine [49].

$\mathrm{CPs}^{\prime}$ potential positions in the ongoing COVID-19 containment challenges are multifaceted [46,47]. For instance, [19] surmised in late 2020 the possibility that the relaxation of travel restrictions could trigger further waves of infections and deaths if suitable precautions such as universal standardised testing were not in place. The situation around the COVID-19 pandemic, on virus variants infection rates, deaths, vaccine efficacy population immunity, and other treatments, continues to evolve. There is a growing consensus that COVID-19 will be endemic [50], and despite the global vaccination effort, border and community lockdowns will have to be implemented to contain the virus [51,52].

\subsection{Cooperation between CPs and the Tourism Sector}

Furthermore, [53] suggests the need to monitor the pandemic, ensure there are indicators of possible virus resurgence and reinfection, have a programme to protect residents from infection, and have a robust testing regime for tourists. Some governments have recently engaged CPs to facilitate tourism recovery [54,55]. For instance, passengers who need to perform a test when leaving the Region of Madeira in Portugal to return to their country of origin may opt to perform a TRAg test for COVID-19 in CPs, adherent to the massive testing campaign. In France, travellers from the US need to apply for a health pass that indicates their vaccination status through a dedicated $\mathrm{CP}$ when arriving in the country. Together with their professionalism, pandemic preparedness, and the accessibility of $\mathrm{CPs}$ at the community level - which have been repeatedly reported since the beginning of the pandemic [46,47] — collaboration at the interface between the tourism and travel sectors, and the health sector through CPs, may show potential for enhancing tourism's recovery strategies.

\subsection{Communication between CPs and the Tourism Sector}

CPs have also shown a willingness and readiness to provide testing venues for COVID19 [56], and are strategically and physically well placed within the community and accessible to tourists, with the ability to communicate real-time COVID-19 health data to the tourism sector. CPs are acknowledged for the essential role they play in maintaining and monitoring public health, offering capacity, anonymity, as well as flexible and informal environments [57]. As such, CPs can be an early warning system to notify the tourism sector and authorities on changing COVID-19 conditions in the community and for visitors (i.e., possible new cases). CPs may have established links to emergency agencies, such as hospitals, as part of the public health sector. In preventing the possible spread of COVID-19 within hotels by guests, guidance issued by the World Health Organisation explicitly suggests pharmacy services be available as a service to offer within or outside the property [58].

\subsection{Cooperation between CPs and the Tourism Sector}

The medical literature concerns the future emergence and threats of another global pandemic $[59,60]$. With this knowledge, the possibility of a tourism industry in a state of flux evolves between lockdowns and recovery attempts. In the past century, we have witnessed an increasing number of new viruses and emerging infectious disease events, which has significantly risen in recent years, including MERS, EBOLA, ZIKA, and SARS [60,61]. 
The links between globalisation and infectious diseases in terms of changes in disease distribution, transmission rate, and disease management have been well documented [62] With the warning that another pandemic is imminent, tourism cities and countries need to be better prepared to manage the fallout and recovery. It is crucial that CPs and tourism start and then maintain cooperation to continually assess the community's evolving pandemic landscape so that borders may remain open and travel mobility is sustained.

\section{Methodology}

We examined eight pharmacy and eight tourism professionals' perceptions towards collaboration to facilitate and sustain a COVID-19 exit and tourism recovery in Macao. A sample size of sixteen senior industry executives was used in this study. This rationale was deemed adequate based on similar sample sizes used in previous exploratory research on tourism stakeholder collaboration [51,63-65], and considering the informational power the stakeholders might hold [66]. As senior professionals in Macao, their views and actions could influence future collaboration efforts.

We used a purposive sampling technique; this technique was used to reach critical informants in recent COVID-19 research. Our respondents had to meet specific criteria. They had to work in Macao's tourism or pharmaceutical industries at a senior level. This requirement included ownership, industry representative, management, or executive position. The selection of only those with relative 'power' or 'interest' in tourism recovery from a crisis is essential [67]. The tourism professionals worked in various principal roles within the hotel sector, travel agency, convention and exhibitions, aviation, and integrated resort development. Similarly, convenience sampling was also used to recruit key stakeholders of the pharmacist profession who were involved in service planning and business operation. The overall sample was adjusted for even representativeness of the tourism industry and the pharmacist profession.

In the study's first phase, we conducted a pilot of the questions with three pharmacist professionals and three senior hospitality executives. These six individuals were not included in the final sample. Slight amendments were made to the questions. It was suggested to be more explicit to the potential respondents regarding the study's intention to determine how Macao's pharmaceutical and tourism industries could partner together. This establishes a better two-way communication process with visitors to keep the city safe from COVID-19. The pilot feedback also suggested using 'cross-industry collaboration' rather than 'cross-disciplinary research' as a term more identifiable by industry practitioners. A final suggestion was to split question four to ask about the actions of pharmacists and tourism executives specifically. The survey instrument was adjusted based on these suggestions, with six questions finalised (see Table 1).

The interviews were constructed based on the grounded theory method. Being a structured and, at the same time, flexible methodology, grounded theory was deemed appropriate for this study's purpose, as little is known about the current question of interests. The grounded theory uses inductive reasoning to identify themes that uncover a process inherent to the substantive inquiry area [68,69]. An invitation and a participant information statement were sent to potential participants via email. Written or oral consent was obtained from participants before each interview. The interviews were conducted either in the respondent's office in Macao or at a video conference in 2020. Online interviewing was previously adopted during COVID-19 social distancing mandates [70]. The interviews were conducted by a tourism academic and a pharmacist academic trained and experienced on grounded theory and qualitative research approaches, and who were familiar with the local status and international trends of pandemic management. Each semi-structured interview took approximately 50-60 min and was recorded with the respondent's consent given. 
Table 1. Pharmacy and tourism industry interview questions.

\begin{tabular}{|c|c|c|c|}
\hline & Question & Probes & Literature \\
\hline 1 & $\begin{array}{l}\text { What are the values and } \\
\text { expectations of cross-industry } \\
\text { collaboration to the COVID-19 } \\
\text { management? }\end{array}$ & $\begin{array}{l}\text { What is the value and contribution of a } \\
\text { network of pharmacists to the recovery } \\
\text { strategy of tourism industry? What } \\
\text { resources can be part of this collaboration } \\
\text { (such as information sharing, skills and } \\
\text { knowledge exchange). }\end{array}$ & $\begin{array}{l}\text { [71] Cioccio and Michael; [72] } \\
\text { Fyall, Garrod and Wang; [73] } \\
\text { Holmes et al. }\end{array}$ \\
\hline 2 & $\begin{array}{l}\text { What are the challenges that you } \\
\text { see impeding the cross-industry } \\
\text { collaboration? }\end{array}$ & $\begin{array}{c}\text { How is the network established? Who } \\
\text { adopts the leadership role? How is trust } \\
\text { established in the collaboration? How are } \\
\text { data shared? }\end{array}$ & $\begin{array}{l}\text { [74] Jamal and Getz; [75] Graci; } \\
\text { [76] Scarpino and Gretzel; [61] } \\
\text { Novelli, Burgress, Jones, } \\
\text { and Ritchie. }\end{array}$ \\
\hline 3 & $\begin{array}{l}\text { What are the enablers that will help } \\
\text { facilitate the cross-disciplinary } \\
\text { collaboration for Macao COVID-19 } \\
\text { tourism recovery strategy? }\end{array}$ & $\begin{array}{c}\text { What are the shared views or goals? What } \\
\text { incentives are provided to enable and } \\
\text { sustain collaboration? }\end{array}$ & $\begin{array}{l}\text { [77] Ansell and Gash, [78] } \\
\text { Kumar and Banerjee. }\end{array}$ \\
\hline 4 & $\begin{array}{l}\text { What is the priority of actions by } \\
\text { pharmacists / tourism to create the } \\
\text { strategy that builds the } \\
\text { collaboration? }\end{array}$ & $\begin{array}{l}\text { What does the action plan look like to help } \\
\text { foster a collaborative relationship between } \\
\text { the tourism industry and pharmacists? } \\
\text { What is the role of government? Who is } \\
\text { responsible for doing what? What is the } \\
\text { format of the collaboration efforts } \\
\text { (taskforce, regular meeting)? }\end{array}$ & $\begin{array}{c}\text { [79] Ritchie; [67] Jiang and } \\
\text { Ritchie. }\end{array}$ \\
\hline 5 & $\begin{array}{l}\text { How should the collaborative } \\
\text { relationship be monitored and } \\
\text { evaluated? }\end{array}$ & $\begin{array}{l}\text { Who takes the leadership role in this new } \\
\text { collaborative mechanism? Who provides } \\
\text { the financing and follow-up actions? }\end{array}$ & $\begin{array}{l}\text { [76] Scarpino and Gretzel; [61] } \\
\text { Novelli, Burgress, Jones, and } \\
\text { Ritche. }\end{array}$ \\
\hline 6 & $\begin{array}{l}\text { If the collaborative relationship is to } \\
\text { be sustained even after COVID-19, } \\
\text { how should this be done? }\end{array}$ & $\begin{array}{l}\text { How should the collaborative relationship } \\
\text { be sustained, and if so, for how long? Will } \\
\text { informal or shadow networks emerge to } \\
\text { influence and control? Will safe spaces be } \\
\text { created to allow people to learn together, } \\
\text { with a common understanding of a crisis, } \\
\text { to permit collaborative resilience to form? }\end{array}$ & $\begin{array}{l}\text { [80] Jamal and Stronza; [81] } \\
\text { Bullock, Armitage and Mitchell; } \\
\text { [82] Goldstein. }\end{array}$ \\
\hline
\end{tabular}

The interview guide was developed based on the current literature about pandemic management in the tourism industry and the pharmacist sector, as well as suggested approaches of collaborative efforts $[59,64,83-86]$. The participants were first asked about their values and expectations of cross-disciplinary collaboration between the tourism industry and pharmacists for the Macao COVID-19 tourism recovery strategy. Questions about the challenges and enablers related to developing and fostering such collaboration followed. Participants were then asked questions such as "What is the priority of actions to create the strategy that builds the collaboration?" and "How should the collaborative relationship be monitored and evaluated?" to yield insights from a practical viewpoint.

After the first six interviews, we reassessed the interview guide and found that although further revisions were not needed, prompts to questions about challenges and enablers were deemed necessary for some participants. After the first 13 interviews, there were no new themes provided by the participants, reaching a point of saturation. Three more interviews were then carried out to confirm data saturation. The audio recordings of the six questions (Table 1) were transcribed verbatim immediately following each interview. Some interviews conducted in Cantonese were later translated into English.

A thematic analysis using an inductive approach was employed to allow commonalities and differences amongst the transcriptions to be identified. Themes emerged using open coding, grouping, and categorising. The themes were constantly compared within and between interviews to ensure the analysis represented all perspectives. Excel was used to present the final coding results. Microsoft Excel is user friendly, especially for using grounded theory and open-ended interviews, permitting categories and themes to be input in spreadsheets [87]. The themes were reviewed, refined, and agreed on by the research 
team. Four key themes emerged and were shown to align with the framework: (1) attitudes towards interdisciplinary research and the partnership between health care and tourism (collaborating); (2) the role of CPs in the COVID-19 pandemic (coordinating); (3) major challenges hindering the optimisation of such a partnership (cooperating); and (4) how to engage CPs and tourism professionals (communicating).

\section{Results}

\subsection{Respondents' Demographic Backgrounds}

Table 2 shows the profiles of the 16 interviewees. All were 35 years and over and held senior management positions in the pharmacy industry or the tourism industry.

Table 2. Profile of pharmacists and tourism professionals.

\begin{tabular}{cccc}
\hline Interviewees (Code) & Age (Years) & Gender & Role \\
\hline PH1 & $45-54$ & M & Owner of a community pharmacy \\
PH2 & $45-54$ & F & Manager of a chain pharmacy company \\
PH3 & $35-44$ & Community pharmacist \\
PH4 & $55-64$ & F & $\begin{array}{c}\text { Representative of a pharmacy association } \\
\text { Representative of a pharmacist profession } \\
\text { organisation }\end{array}$ \\
PH5 & $35-44$ & M & Manager of a chain pharmacy company \\
PH6 & $55-64$ & M & Managing Director, Integrated Resort \\
TE1 & $55-64$ & M & Advisor \\
TE2 & $45-54$ & F & Managing Director, Integrated Resort \\
TE3 & $35-44$ & F & Advisor \\
TE4 & $45-54$ & M & Executive Director, Front Office \\
Operations
\end{tabular}

\subsection{The Expectations of Cross-Industry Collaboration towards COVID-19 Management}

The respondents were first asked on their views regarding the value of collaboration and the expectations from this. There was consensus that collaboration between CPs and the tourism sector could assist in a COVID-19 exit strategy. Specifically, the tourism executives provided suggestions on cooperating with $\mathrm{CP}$ services on issues such as vaccination and testing:

'Macao could become a short-term vaccination destination with the best option of vaccines available' (TE5)

'Pharmacists should have an app with multi-lingual live updates by the minute providing info to hotels so they may direct guests and international travellers to the right place' (TE8)

'Testing and speed of results are crucial to tourism recovery. Once a resident or tourist of a destination is tested positive, the drugs and therapeutics must be targeted to these individuals as soon as possible to stop any further spread of the virus' (TE7)

Pharmacists were particularly enthused by the opportunity to cooperate with the tourism sector, recognising the potential for a cross-functional alliance as their pharmacy outlets already received significant tourist visitation due to their high-quality products:

'The cross-over between the tourism industry and the community pharmacy is nothing new. Tourists come to Macao for leisure, but many tourists are also very interested in what we sell in the pharmacy. It is still a common perception that what we sell in 
pharmacy in Macao is of high-quality assurance compared to what is available in their hometown. So, there is a general trust in the practice's reliability in the pharmacy in Macao among the tourists' (PH1)

'It is a matter of building trust for the tourists, and we pharmacists should be a part of it. To this end, we need to be more innovative in adjusting to this new norm. I hope that the interface between our profession and the tourist industry brings us new opportunities to become more than just a retail sales person' (PH3)

The pharmacists generally projected the need to elevate their professional role in virus control and prevention measures to protect the community and tourists: Some pharmacists already work within tourism with coordination only, and formalisation is required:

'With our distribution all over Macao, we can become a strong safety net offering advice, education and assurance for people we serve... . However, we need a mechanism to move the pharmacies as a joint force instead of individual business operations. The collaboration with the tourist industry, if well structured and well orchestrated, will be a great opportunity for us to continue being a positive factor in protecting the public, including the tourists' (PH5)

\subsection{The Challenges Impeding Cross-Industry Collaboration}

The respondents were further questioned on the challenges to tourism and pharmaceutical industry cooperation. Some in tourism underscored the challenge of varied priorities and establishing goal congruence, given the tourism sector's eagerness to generate revenues as soon as possible:

'The local government is risk averse; hence, their key concern is that tourists will not transmit the COVID-19 disease to residents, yet the tourism industry is coming to a crossroads on survival, and with that, there will be conflict and friction because the tourism industry and the health authorities may desire different outcomes' (TE3)

'Yes, business and revenue are important, but the perspective here is to create a service model together that addresses the concerns and needs of the potential travellers. For this, I am afraid that neither we nor the tourist industry has a lot of insights so far' (PH6)

One challenge highlighted by both parties was how to manage the collaboration process, and who resumes leadership, as no collaboration has previously existed; as the industry suffers, there is a shift in focus to generate revenues:

'I can see many positive outcomes through closer collaboration with the tourist industry, but the problem here is how to get it started? We hardly have any formal or professional industry-to-industry communication before. How can we, people from both sides, come to a consensus about the goals we want to achieve and how? I find the idea very meaningful but novel. That means we need strong leadership here to help both sides come together, talk in the same language and work together' (PH2)

'One relies on the Macao Government to do something to prevent COVID-19; therefore, lending themselves to wait and expect that the government do whatever is necessary because of the belief that this is beyond their reach to have an impact. There is no initiative to talk with different stakeholders. There is a lack of dialogue and thinking that others can do their job on their behalf. If the dialogue was not easy when business was running high, now that business is running low, everyone says that they are too busy to stop and reflect' (TE8)

Some pharmacists reflected on the visitor viewpoint of pharmacists and the need to communicate the professional healthcare role to visitors:

'I know my professional responsibilities should extend towards the tourists. I guess I need to have a "blueprint" about what is expected of me and how I should practise meeting the expectations. However, the more troublesome experiences are about the tourists 
themselves. Many of them do not use us as healthcare professionals but just salespersons. They are probably not aware that we are trained and licensed health professionals' (PH3)

\subsection{The 4C's for a Macao COVID-19 Tourism Recovery Strategy}

This was the first time in the literature that pharmacists and tourism professionals had been approached to discuss collaboration as a tactical response to COVID-19 recovery. The responses showed the dimensions of communication, cooperation, and coordination as outcomes, confirming our framework to be appropriate and relevant. The contextual setting shows COVID-19 evolving, and with this, greater uncertainty and risk. Both the tourism and CP sectors can collaborate to pool resources, achieve goal congruence, and observe real-time happenings to gather and communicate intelligence and data. The CPs suggested a need to determine who would lead and how to communicate and share knowledge on this collaboration. This orientation would also manage alternate viewpoints. Some proposed governments should assume a leadership role based on the government's experience, resources, and knowledge for most of 2020 in containing, treating, and monitoring the spread of the virus:

'Maybe some of them are not confident enough to know when and how to make referrals. That needs to be reinforced. At the same time, the public and the tourists need to be educated about us as a health resource at the community level who they can turn to in case of any concerns about the pandemic. Such awareness should be raised so that they know where to look for help and support' (PH4)

'I guess we need to have some sort of initiative to kick start the realisation of this conceptual idea. Pharmacists or pharmacies alone may not be in the position to initiate such communication and further collaboration. Representatives from the tourist industry should take a more proactive role in the initial stage' (PH2)

'I guess this should be a coordinated effort somehow under the government's leadership as this is, after all, an issue of public health and economic recovery for Macao. Based on the past nine months' outbreak experiences, the government has a pivotal role in coordinating different sectors. The government must recognise such collaborative effort' (PH5)

The tourism sector directly referenced greater international recognition on COVID-19 testing and treatments, including vaccination, which could be part of the city's tourism appeal. In partnership with the authorities, some Macao casinos already provide COVID-19 testing on-site for visitors and resident employees, including vaccination drives for staff. In a pooling of resources, this could be expanded in partnership with CPs:

'There should be an internationally recognised certification of testing, results, drugs and therapeutics in Macao' (TE7)

'The government needs to arrange a certification process to qualify pharmacists to do vaccination, but this is not consensual because these new vaccines are more unpredictable than the ones previously developed over the decades. The government needs to address this to the medical community so that the Universities and main accreditation bodies are involved' (TE1)

'The use of Macao as a mass vaccination destination should be considered ... VIP gaming facilities have in-house hospitals to provide gamblers and their families with a vaccine as part of the package. Casinos could reinvent themselves to become mass "vaccination" (vaccination + visitation) points' (TE5)

\subsection{Collaboration That Creates Actions by Pharmacists and Tourism Professionals}

The contextual setting of the $4 \mathrm{C}$ s framework is essential. The spread of the virus will determine the actions taken by the tourism and pharmaceutical industry. A tourism executive highlighted that the evolution of the pandemic should be closely tracked (TE2). While contained, outbreaks and COVID-19 resurgence have appeared globally, reactivating lockdowns. There was consensus from the tourism and pharmacist respondents that 
communication and building trust and transparency would be key factors to establish collaboration. One pharmacist mentioned that it was too premature to talk about actions when the exact collaboration model had yet to be established (PH3):

'There is currently a lack of transparency between the two, a lack of involvement by each party, and a lack of information shared by each party'(TE2)

'Transparency is always key to this type of strategy, both internally and externally' (TE7)

As the borders were already opening, a sense of urgency on establishing collaboration was described by some pharmacist respondents, and in turn to communicate this cooperation with visitors. Who should pay the costs of this collaboration would need greater discussion too:

'The expectations from each side should be communicated clearly, and an action plan should be designed and followed through. I guess we can try a pilot by engaging one or two chain pharmacy companies in the project. This should proceed quickly as the borders are opening up already, and it will be some time before the key messages can get to the tourists' (PH1)

'It is important for the tourist industry to be committed in terms of communication with the pharmacy sector and provide the support needed. Education, meetings, lobbying, accreditation, and promotion are all actions consuming resources. Really, I don't think pharmacies can bear all the costs nor would they be in any position to provide the resources needed' (PH4)

Some tourism executives mentioned that quality medicines and COVID-19 vaccines would be crucial parts of actioning a communication programme to visitors:

'There should be awareness that the pharmacies are the places to get actual medication versus overpriced supplements' (TE4)

'We need to ensure the authorities overseeing the pharmaceutical industry determine the best COVID-19 vaccines to be imported to the city' (TE5)

\subsection{How the Collaborative Relationship Should Be Monitored and Evaluated}

While the virus outbreak continued globally, the importance of preventing or treating community spread was highlighted as a factor for successful collaboration (TE7). Various actions to measure the collaboration relationship were suggested, such as creating a shared digital platform (TE5) or the level of pharmacist knowledge and input regarding COVID-19 recovery (PH3). Oversight and competence level were also mentioned:

'An independent medical professional body that collaborates with WHO and a regional CDC (like the USA) could review what the Macao authorities are doing in comparison to how the region is handling the evolution of the pandemic, as well as monitoring the new vaccine effectiveness through time' (TE6)

Some pharmacists offered some practical measures for collecting and evaluating data, including how tourists experienced COVID-19-related services:

'As I mention before, the design of the collaboration should have an evaluation mechanism built in already. In the health sector, the use of an ECHO model is common when testing any new interventions. ECHO stands for the economic, clinical and humanistic outcomes. I think the easiest way to evaluate is to monitor the humanistic outcome of the collaboration. For example, using a survey and simply randomly asking the tourists about their experience with certain services provided out of the collaboration would be feasible' (PH5)

'The outcome for us is really about how many more tourists the collaborative services can drive to our pharmacy and how it translates into our business performance. I am trying to be practical here. Eventually, the community pharmacy is a business ... . A professional image is one, but it is not tangible. Positive impact on the business is core. 
With good services and good promotion through the tourism network, I believe there are many advantages for pharmacies to participate' (PH4)

\subsection{How the Collaborative Relationship Should Be Sustained, even after COVID-19}

The tourism sector was the most vocal about sustaining this collaboration as COVID19 continues. Key points were to communicate and grow confidence in professional pharmacist services beyond being regarded solely as retail sales outlets:

'First, there should be legislation or reinforcement on the existing one for pharmacists - an official government certification system which recognises highly qualified pharmacist professionals' (TE5)

'They (pharmacists) need a good public relations campaign to revamp their image: from shops that have sprung up to benefit from Chinese tourism to shops that we can trust actually to sell us what we need'(TE4)

While tourism executives supported future collaboration, some warned that the focus should remain on COVID-19 prevention and control:

'Any outreach to CPS should not cannibalise on resources needed to combat COVID-19' (TE1)

\section{Major Contribution}

\subsection{Theoretical Contribution}

COVID-19 continues to surge, particularly as new virus variants emerge, reactivating travel restrictions and targeted lockdowns and reinforcing the fact that we live in an interconnected world. While there have been some references in the pharmacy literature that due to the complexity of the virus, interdisciplinary research is recommended, tourism literature on COVID-19 recovery is largely silent on working across boundaries with CPs to aid recovery. In our study, we advanced a collaborative framework to include an alliance between tourism and CPs as a sustainable pathway to tourism recovery. The dimensions of communication, coordination, and cooperation were evident throughout the responses from the CPs and tourism executives, confirming our framework as appropriate. While multiple barriers to interdisciplinary research have been cited-one key obstacle being the power imbalances between scholars in the seemingly more rigorous hard (medical) disciplines and those in soft (social science) disciplines [13]—our study provides a first step to initiating interdisciplinary research between the two disciplines of pharmacy and tourism into a singular activity of navigating a collaborative process for sustainable recovery. Our model suggests that further collaboration challenges would need further investigation, such as resource and knowledge sharing, sense making, and empowerment.

\subsection{Practical Contribution}

Based on the qualitative data collected in this study, the collaborative role through the three dimensions of coordination, communication, and cooperation between CPs and tourism can be summarised as three key issues: active surveillance and orientation; public education and sharing explicit knowledge; and actioning a stable supply of medicines and health-related products.

\subsubsection{Active Surveillance and Orientation}

In some destinations, CPs have played an active role in supporting the healthcare system during COVID-19, such as virus screening and clarifying misconceptions about virus treatments [88]. Macao's CPs could extend their role from solely supplying facemasks to include recording, documenting, and screening suspected cases, patient referrals, and flu-related sales through the already-established centralised pharmacy computer system and database. Data collected could be communicated with the tourism sector. These would be flagged with Macao's CDC [25]. The CPs could distil this knowledge in a format that could assist the tourism, travel, and hospitality sectors in planning and preparation. 


\subsubsection{Tourist and Public Education}

Disseminating up-to-date, overt, and scientific data to inform the community and visitors on COVID-19 infection prevention protocols is typical at destinations and through online and offline communication efforts. There has been misleading information on COVID-19 and rumours that have sparked public panic, false narratives, and possible additional virus spread [89]. In research conducted in Europe, false rumours and misleading information have been spread throughout the pandemic, causing harm to individuals such as discouraging proper protective actions; being tricked into purchasing fake protection; promoting false remedies; misrepresenting how the virus spreads; and victimising alleged spreaders of the virus [90]. As part of our collaboration efforts, Macao's CPs could inform and reinforce correct messaging to the community and tourists on personal hygiene protocols, mask wearing, social distancing, environmental hygiene, and any evolving information about the virus; these measures could all help sustain tourism's recovery.

\subsubsection{Provision of Medicines and Other Quality Health-Related Products}

Healthcare services have been put under intense pressure during the pandemic [91]. There has been the potential for a shortage of prescription drugs [89]. This scarcity could occur with face masks, disinfectants, and hand-rub gels. CPs could address shortfalls of medical materials to neighbourhoods. Resource pooling between the tourism sector and CPs could ensure and predict adequate materials to protect staff, community members, and visitors. CPs could also administer the COVID-19 vaccine [88], including vaccine 'booster' doses to residents and visitors, as part of future collaborative planning, given that COVID-19 will be endemic.

The immediate need to manage the impact of COVID-19 on tourism and increase visitor arrivals should be a catalyst to merge two seemingly distinct disciplines, to provide well-informed collaborative decisions and actions for best practices on tourism recovery during the pandemic. Increasing visitor numbers will undoubtedly put more pressure on an already-strained healthcare system, with CPs in some destinations already helping alleviate this. Recovery collaboration between private and public sectors, through which communication and promotion can be better achieved, has been a critical component of a tourism crisis management and recovery plan [92]. When COVID-19 first emerged in Macao, McCartney (2020) advocated for public and private tourism partnerships as key to Macao's revival and an exit from COVID-19. Macao's hospitality industry support has already extended medical assistance during COVID-19, providing quarantine hotels and on-site COVID-19 testing.

\section{Discussion}

Disparities in the vaccination rollout globally and new virus variants confirm that travel restrictions will continue, particularly in developing destinations. Just over half of the world has received one vaccine dose, with only $6.2 \%$ of people in low-income countries receiving one vaccine dose $[58,93]$. Globally, the tourism industry has attempted to remove travel restrictions, only to relapse, challenged to move from this cycle to a more sustainable recovery model. Our framework was established within the context of destinations required to seek feedback on the virus's epidemiology. Research continues working on the effectiveness of vaccines on new virus variants. The alliance between CPs and tourism could manage and minimise the risk and uncertainty of COVID-19 through shared knowledge to present suitable courses of action for tourism recovery.

CPs have undertaken crucial roles during the pandemic, including being a primary supplier of protective equipment and disinfectants, a constant educator of hand/environment hygiene and social distancing, an active sensor of suspected cases, and a reliable psychological support source $[20,83,89,94]$. During the early stage of tourism recovery in a crisis, it is essential for host destinations to have a credible plan to provide tourists with assurance, advice, and even appropriate referral protocols [95]. Infected tourists are notable spreaders of the virus, prompting the call for early case recognition, individual isolation, contract 
tracing, and public awareness [96]. In China, pharmacists provided the necessary preventive and treatment medications in response to the COVID-19 outbreak. These included a timely and adequate supply of preventive and treatment services, medicines, as well as educating and updating the community on the virus [89].

In providing guidelines and advice for pharmacists on the COVID-19 pandemic, [97] affirmed that 'community pharmacies in outbreak-affected and unaffected countries are often the first point contact with the health system for those with health-related concerns or simply in need of information and reliable advice'. Macao's CPs in one of the first areas that had confirmed cases of the viral infection outside Mainland China-and one of the first cites globally to emerge with a tourism recovery trajectory-joined the collaborative efforts in supporting local health emergency preparedness and response arrangements.

\section{Results Recommendations}

The results of the study are consistent with the hypothesis that cross-industry collaboration was deemed relevant by the tourism sector and the pharmacist sector for its implications in strengthening the post-pandemic recovery strategy. Our study and framework are timely and relevant for initiating a collaborative response to fortify countermeasures against the dramatic disruption and fallout affecting tourism. Our cross-interdisciplinary study revealed a high agreement in forming alliances between CPs and the tourism industry. These findings affirm that, for the first time in the COVID-19 response literature, this collaboration with dimensions of cooperation, communication, and coordination is a viable and integral part of the continued COVID-19 exit strategy for the tourism industry. These are illustrated in Figure 4.

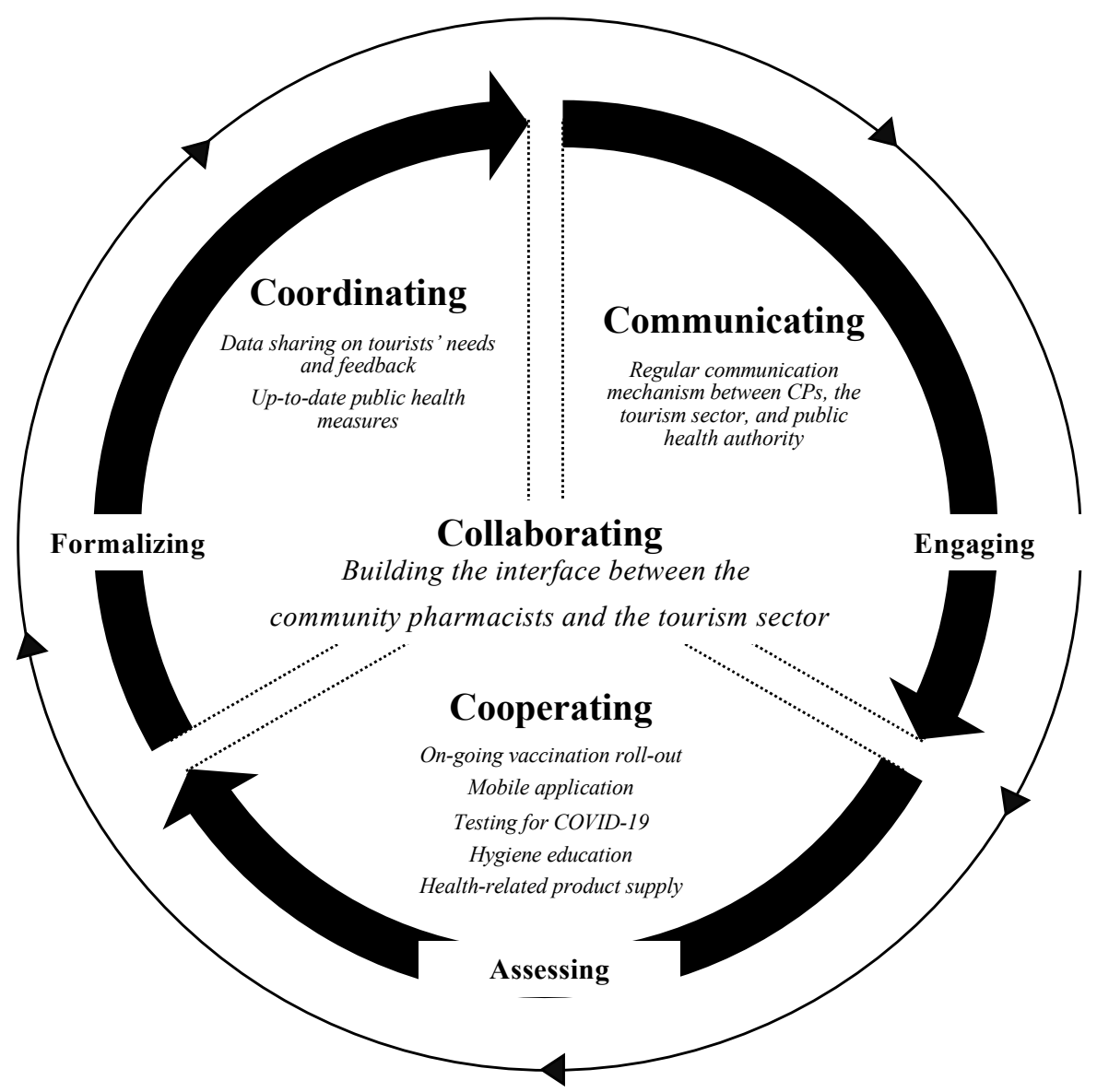

Figure 4. Emerging model of collaborative practices after responses from Macao's CPs and tourism sector. 
As a global health emergency, CPs could provide a network of valuable healthcare resources, tracking healthcare and communicating alerts towards tourism destination recovery efforts. It was found that CPs and tourism professionals could have a back-andforth reciprocal relationship and participation towards a shared goal of eliminating or managing COVID-19, to aid Macao's tourism industry recovery. This issue of collaboration between public and private sectors to reach a consensus on recovery efforts in an emergency is a consistent theme in previous disaster management studies [38].

Despite this willingness found in our study to collaborate, several challenges to this potential collaboration were mentioned, such as determining who would initiate the partnerships, take the leadership role, as well as provide the funding and other resources to maintain. Indeed, [98] proposed that DMOs (Destination Management Organisations) take a focal role in a COVID-19 tourism recovery plan-in this case, Macao's DMO, the government-run Macao SAR Government Tourism Office, could spearhead the initiative [23]. The need to consolidate the information to determine suitable actions is also noteworthy. The results in our study show an over-reliance on the government to initiate, fund, and legislate this collaborative body. In fact, the issue of looking to government for financial assistance, compensation, and rapid decision-making leadership in an ongoing tourism crisis is not new in the literature [79]. It has been argued that DMOs are a key knowledge broker across stakeholders during a crisis [99].

Another challenge found in the study, was on effectively communicating the rationale and aims of this cooperation to visitors and residents, as a means to manage intelligence gathering, and deciding on appropriate courses of action, with an awareness that the pandemic persists globally. The tourism industry was particularly forthcoming on ways to maintain this relationship in the longer term, with one idea being to leverage the resources of CPs with the provision of vaccines and COVID-19 testing as part of city distinctiveness and visitor appeal.

Mechanisms to incentivise $\mathrm{CPs}$ are essential, as the responses showed that $\mathrm{CPs}$ operate retail outlets with a focus on revenue creation. As suggested in the study, these incentives can be linked to accreditation mechanisms and tourism promotion efforts to direct visitors to the pharmacies-and in the longer term, being an active partner in Macao's tourism network and future tourism actions. A shared centralised IT database was a recommendation from this study. Importantly, the collaboration between the two sectors, once initiated and developed, should remain robust and be closely monitored and adapted where necessary according to a set of pre-defined outputs and outcomes.

\section{Conclusions}

Reviewing published papers on tourism risk and crisis and disaster management, Ritchie and Jiang (2019) categorise tourism crisis management into the three major stages of 'preparedness and planning', 'response and recovery', and 'resolution and reflection'. The researchers also highlight the limited literature on business response and recovery resolutions post-crisis. Tourism destinations are tasked with avoiding relapsing to tourism shutdowns and travel restrictions. Once borders are re-opened, destinations are in imminent danger of rising COVID-19 cases and hospitalisations. We have suggested the novel position that a tourism recovery strategy from this pandemic for Macao could occur more safely through a collaborative partnership with the extensive network of pharmacists throughout the city, as well as within the community and popular tourism sites. Macao has re-opened with the common goal and shared expectations of increasing numbers of visitors, creating a greater need to manage and share knowledge across sectors. Due to mask issuance and mandates throughout the city, licensed pharmacists are already recorded within the central database of the Macao health authorities, which enables quick outreach. While Macao looks to the visitor development phase, harnessing the continued collaboration and network of CPs with tourism could strengthen ongoing tourism crisis learning and communication. Such a dynamic partnership could instil further confidence among the community and visitors, creating positive perceptions of Macao being a safe city to visit. 


\section{Limitations and Future Scope}

We used a purposive sample, as recommended in the literature. Nonetheless, the respondents' opinions may not be representative of the entirety of Macao's tourism or pharmacist sectors. Being the first attempt to consider a pharmacist and tourism partnership, this study could be further enlarged to include more healthcare professionals, as well as tourism and hospitality providers. This study only considers the private sector's opinions, not the public sector or the community. There are other healthcare professionals, such as doctors and nurses, some of whom have treated COVID-19 patients and have been part of the vaccination process. Macao's health bureau has been pivotal in mask distribution, COVID-19 testing, hotel quarantine logistics, vaccine purchases, vaccination rollout, and regular updates on COVID-19, including restrictions and mandates. Since the respondents in this study mentioned the importance of the government in COVID-19 policy and recovery strategies, our study could be extended to those in the government's healthcare, immigration, public security, and tourism authorities. Our collaborative framework would need further investigation. Macao's CPs have an extensive reach throughout the city (Figure 2) and, as such, our results may not be dissimilar to those in global tourism cities that have networks of pharmacies; thus, this study can be replicated elsewhere.

Author Contributions: Conceptualisation, G.M., C.O.L.U. and J.F.P.; methodology, G.M., C.O.L.U. and J.F.P.; formal analysis G.M., C.O.L.U. and J.F.P.; writing-original draft preparation G.M., C.O.L.U. and J.F.P.; writing-review and editing, G.M., C.O.L.U. and J.F.P. All authors have read and agreed to the published version of the manuscript.

Funding: This research received no external funding.

Institutional Review Board Statement: The study was conducted according to the guidelines of the Declaration of Helsinki and approved by the University of Macau Ethics Panel (number SSHRE20APP028-ICMS and approval on 18 September 2020).

Informed Consent Statement: With the informed consent obtained from all participants involved in the study, each interview was audio-recorded. The interviews were conducted face-to-face in private conference rooms chosen by the participant. A participant information statement outlining the study was provided to all the participants prior to the start of the interview.

Data Availability Statement: Data is contained within this article.

Conflicts of Interest: The authors declare no conflict of interest.

\section{References}

1. Hernández, J.M. SARS-CoV-2 Risk Misclassification Explains Poor COVID-19 Management. Lancet Lond. Engl. 2020, 396, 1733-1734. [CrossRef]

2. Rodríguez-Antón, J.M.; Alonso-Almeida, M. del M. COVID-19 Impacts and Recovery Strategies: The Case of the Hospitality Industry in Spain. Sustainability 2020, 12, 8599. [CrossRef]

3. Atalan, A. Is the Lockdown Important to Prevent the COVID-19 Pandemic? Effects on Psychology, Environment and EconomyPerspective. Ann. Med. Surg. 2020, 56, 38-42. [CrossRef]

4. Oraby, T.; Tyshenko, M.G.; Maldonado, J.C.; Vatcheva, K.; Elsaadany, S.; Alali, W.Q.; Longenecker, J.C.; Al-Zoughool, M. Modeling the Effect of Lockdown Timing as a COVID-19 Control Measure in Countries with Differing Social Contacts. Sci. Rep. 2021, 11, 3354. [CrossRef] [PubMed]

5. Vinceti, M.; Filippini, T.; Rothman, K.J.; Ferrari, F.; Goffi, A.; Maffeis, G.; Orsini, N. Lockdown Timing and Efficacy in Controlling COVID-19 Using Mobile Phone Tracking. EClinicalMedicine 2020, 25, 100457. [CrossRef]

6. Plümper, T.; Neumayer, E. Lockdown Policies and the Dynamics of the First Wave of the SARS-CoV-2 Pandemic in Europe. J. Eur. Public Policy 2020, 27, 1-21. [CrossRef]

7. Duan, L.; Zhu, G. Psychological Interventions for People Affected by the COVID-19 Epidemic. Lancet Psychiatry 2020, 7, 300-302. [CrossRef]

8. Bausch, T.; Gartner, W.C.; Ortanderl, F. How to Avoid a COVID-19 Research Paper Tsunami? A Tourism System Approach. J. Travel Res. 2021, 60, 467-485. [CrossRef]

9. Purcell, W.M.; Burns, O.; Voss, A. COVID-19 and Sustainable Tourism. In COVID-19: Paving the Way for a More Sustainable World; Leal Filho, W., Ed.; World Sustainability Series; Springer International Publishing: Cham, Switzerland, 2021; pp. 163-184, ISBN 978-3-030-69284-1. 
10. Helble, M.; Park, C.-Y.; Cho, W.H.; Cortes, S.F. Can Vaccination Help Restart Tourism? ADB Briefs; Asian Development Bank: Manila, Philippines, 2021.

11. Wang, M.; Kunasekaran, P.; Rasoolimanesh, S.M. What Influences People's Willingness to Receive the COVID-19 Vaccine for International Travel? Curr. Issues Tour. 2021, 1-6. [CrossRef]

12. McCartney, G.; Pinto, J. Macao's COVID-19 Responses: From Virus Elimination Success to Vaccination Rollout Challenges. Lancet Reg. Health-West. Pac. 2021, 11, 100169. [CrossRef]

13. Wen, J.; Wang, W.; Kozak, M.; Liu, X.; Hou, H. Many Brains Are Better than One: The Importance of Interdisciplinary Studies on COVID-19 in and beyond Tourism. Tour. Recreat. Res. 2021, 46, 310-313. [CrossRef]

14. Koch, S.; Yoon, L.; Gils, B. From the Exposome to the Socioexposome in COVID-19 Research-A Call for More Multidisciplinary Research. JAMA Netw. Open 2020, 3, e2032287. [CrossRef]

15. O'Connor, R.C.; Hotopf, M.; Worthman, C.M.; Perry, V.H.; Tracey, I.; Wessely, S.; Arseneault, L.; Ballard, C.; Christensen, H.; Silver, R.C.; et al. Multidisciplinary Research Priorities for the COVID-19 Pandemic-Authors' Reply. Lancet Psychiatry 2020, 7, e44-e45. [CrossRef]

16. Parajuli, R.R.; Mishra, B.; Banstola, A.; Ghimire, B.R.; Poudel, S.; Sharma, K.; Dixit, S.M.; Sah, S.K.; Simkhada, P.; van Teijlingen, E. Multidisciplinary Approach to COVID-19 Risk Communication: A Framework and Tool for Individual and Regional Risk Assessment. Sci. Rep. 2020, 10, 21650. [CrossRef]

17. Arencibia-Jorge, R.; García-García, L.; Galban-Rodriguez, E.; Carrillo-Calvet, H. The Multidisciplinary Nature of COVID-19 Research. Iberoam. J. Sci. Meas. Commun. 2021, 1, 394312. [CrossRef]

18. Dawoud, D. Emerging from the Other End: Key Measures for a Successful COVID-19 Lockdown Exit Strategy and the Potential Contribution of Pharmacists. Res. Soc. Adm. Pharm. 2021, 17, 1950-1953. [CrossRef]

19. Peto, J.; Alwan, N.A.; Godfrey, K.M.; Burgess, R.A.; Hunter, D.J.; Riboli, E.; Romer, P.; Buchan, I.; Colbourn, T.; Costelloe, C.; et al. Universal Weekly Testing as the UK COVID-19 Lockdown Exit Strategy. Lancet 2020, 395, 1420-1421. [CrossRef]

20. Ung, C.O.L. Community Pharmacist in Public Health Emergencies: Quick to Action against the Coronavirus 2019-NCoV Outbreak. Res. Soc. Adm. Pharm. RSAP 2020, 16, 583-586. [CrossRef]

21. McCartney, G.; Pinto, J.; Liu, M. City Resilience and Recovery from COVID-19: The Case of Macao. Cities 2021, 112, 103130. [CrossRef]

22. Macao SAR Government. Statistics and Census Service Statistics - Statistics and Census Service. Available online: https: / / www.dsec.gov.mo/en-US/Statistic?id=402 (accessed on 14 December 2021).

23. Macao SAR Government Tourism Office. Measures and Important Notes for Tourists Visiting Macao-Macao Government Tourism Office. Available online: https://www.macaotourism.gov.mo/en/article/notice/covid19-notice (accessed on 15 December 2021).

24. World Travel and Tourism Council. Travel \& Tourism Economic Impact I World Travel \& Tourism Council (WTTC). Available online: https: / / wttc.org/Research/Economic-Impact (accessed on 14 December 2021).

25. Macao SAR Government. Health Bureau News. Available online: https://www.ssm.gov.mo/Portal/portal.aspx?lang=pt (accessed on 23 March 2021).

26. Zhang, M.Y.; Chong, W.K.; Hu, H.; Wang, Y. Pharmacy-Perceived Consumer Preferences: A Survey of Community Pharmacies in Macau. J. Med. Mark. 2014, 14, 41-48. [CrossRef]

27. Macao SAR Government. Cartography and Cadastre Bureau Cartography and Cadastre Bureau. Available online: https: //www.dscc.gov.mo/en/geographical_typeMap.html (accessed on 14 December 2021).

28. Brüning, H. Over 200 Million 'Government Masks' Sold in Macau. Macau Post Dly. 2021, 112, 103130.

29. Choi, B.; Pak, A. Multidisciplinarity, Interdisciplinarity and Transdisciplinarity in Health Research, Services, Education and Policy: 1. Definitions, Objectives, and Evidence of Effectiveness. Clin. Investig. Med. Médecine Clin. Exp. 2007, 29, 351-364.

30. Iskander, J.K.; Bianchi, K.M. Changes in the Scientific Information Environment During the COVID-19 Pandemic: The Importance of Scientific Situational Awareness in Responding to the Infodemic. Health Secur. 2021, 19, 82-87. [CrossRef]

31. Yang, S.; Carlson, J.R.; Chen, S. How Augmented Reality Affects Advertising Effectiveness: The Mediating Effects of Curiosity and Attention toward the Ad. J. Retail. Consum. Serv. 2020, 54, 102020. [CrossRef]

32. Peek, L.; Guikema, S. Interdisciplinary Theory, Methods, and Approaches for Hazards and Disaster Research: An Introduction to the Special Issue. Risk Anal. Off. Publ. Soc. Risk Anal. 2021, 41, 1047-1058. [CrossRef]

33. Sharma, G.D.; Thomas, A.; Paul, J. Reviving Tourism Industry Post-COVID-19: A Resilience-Based Framework. Tour. Manag. Perspect. 2021, 37, 100786. [CrossRef] [PubMed]

34. Robina-Ramírez, R.; Sánchez, M.S.-O.; Jiménez-Naranjo, H.V.; Castro-Serrano, J. Tourism Governance during the COVID-19 Pandemic Crisis: A Proposal for a Sustainable Model to Restore the Tourism Industry. Environ. Dev. Sustain. 2021, 1-22. [CrossRef] [PubMed]

35. Santos, M.A.; Gonzalez, M.C.; Haegeman, K.; Rainoldi, A. Behavioural Changes in Tourism in Times of COVID-19. The Joint Research Centre Science for Policy Report; European Commission: Brussels, Belgium, 2020.

36. Bedwell, W.L.; Wildman, J.L.; DiazGranados, D.; Salazar, M.; Kramer, W.S.; Salas, E. Collaboration at Work: An Integrative Multilevel Conceptualization. Hum. Resour. Manag. Rev. 2012, 22, 128-145. [CrossRef]

37. Martin, R.; Sunley, P.; Gardiner, B.; Tyler, P. How Regions React to Recessions: Resilience and the Role of Economic Structure. Reg. Stud. 2016, 50, 561-585. [CrossRef] 
38. Kapucu, N.; Garayev, V. Collaborative Decision-Making in Emergency and Disaster Management. Int. J. Public Adm. 2011, 34, 366-375. [CrossRef]

39. Clarke, A.; Crane, A. Cross-Sector Partnerships for Systemic Change: Systematized Literature Review and Agenda for Further Research. J. Bus. Ethics 2018, 150, 303-313. [CrossRef] [PubMed]

40. Schuh, G.; Potente, T.; Varandani, R.; Hausberg, C.; Fränken, B. Collaboration Moves Productivity to the Next Level. Procedia CIRP 2014, 17, 3-8. [CrossRef]

41. Rice, R.; Atkin, C. Public Communication Campaigns, 3rd ed.; SAGE Knowledge: Thousand Oaks, CA, USA, 2001.

42. Flanagin, A.J.; Bator, M. The Utility of Information and Communication Technologies in Organizational Knowledge Management. In Communication and Organizational Knowledge; Routledge: London, UK, 2010; ISBN 978-0-203-87450-9.

43. Porter, M.E. Clusters and the New Economics of Competition. Harv. Bus. Rev. 1998, 76 6, 77-90.

44. Kohn, A. No Contest: The Case Against Competition; Houghton Mifflin Harcourt: Boston, MA, USA, 1992; ISBN 978-0-395-63125-6.

45. Han, E.; Tan, M.M.J.; Turk, E.; Sridhar, D.; Leung, G.M.; Shibuya, K.; Asgari, N.; Oh, J.; García-Basteiro, A.L.; Hanefeld, J.; et al. Lessons Learnt from Easing COVID-19 Restrictions: An Analysis of Countries and Regions in Asia Pacific and Europe. Lancet 2020, 396, 1525-1534. [CrossRef]

46. Cadogan, C.A.; Hughes, C.M. On the Frontline against COVID-19: Community Pharmacists' Contribution during a Public Health Crisis. Res. Soc. Adm. Pharm. RSAP 2021, 17, 2032-2035. [CrossRef] [PubMed]

47. Visacri, M.B.; Figueiredo, I.V.; Lima, T.d.M. Role of Pharmacist during the COVID-19 Pandemic: A Scoping Review. Res. Soc. Adm. Pharm. RSAP 2021, 17, 1799-1806. [CrossRef] [PubMed]

48. U.S. Department of Health and Human Services Trump Administration Partners with Chain and Independent Community Pharmacies to Increase Access to Future COVID-19 Vaccines. Available online: https://www.hhs.gov/about/news/2020/11/12 /trump-administration-partners-chain-independent-community-pharmacies-increase-access-future-covid-19-vaccines.html (accessed on 28 April 2021).

49. CDC-Center for Disease Control Influenza Vaccinations Administered to Adults in Pharmacies and Physician Medical Offices, United States I FluVaxView I Seasonal Influenza (Flu) | CDC. Available online: https://www.cdc.gov/flu/fluvaxview/ dashboard/vaccination-administered.html (accessed on 28 April 2021).

50. Lau, Y. Looking beyond COVID-19 as a Pandemic. HONG KONG Med. J. 2021, 27, 88-89. [CrossRef]

51. Kaushal, V.; Srivastava, S. Hospitality and Tourism Industry amid COVID-19 Pandemic: Perspectives on Challenges and Learnings from India. Int. J. Hosp. Manag. 2021, 92, 102707. [CrossRef]

52. Uğur, N.G.; Akbıyık, A. Impacts of COVID-19 on Global Tourism Industry: A Cross-Regional Comparison. Tour. Manag. Perspect. 2020, 36, 100744. [CrossRef]

53. Chang, C.-L.; McAleer, M.; Ramos, V. A Charter for Sustainable Tourism after COVID-19. Sustainability 2020, 12, 3671. [CrossRef]

54. French Government Ministry of Solidarity and Health How to obtain a health pass in case of vaccination abroad? Available online: https: / / www.sante.fr/how-to-obtain-a-french-health-pass (accessed on 15 December 2021).

55. Governo Regional da Madeira. Resolução n. ${ }^{\circ}$ 1208/2021 da Presidência do Governo Regional da Madeira; Journal Oficial da Região Autónoma da Madeira: Madeira, Portugal, 2021.

56. Mukattash, T.L.; Jarab, A.S.; Mukattash, I.; Nusair, M.B.; Farha, R.A.; Bisharat, M.; Basheti, I.A. Pharmacists' Perception of Their Role during COVID-19: A Qualitative Content Analysis of Posts on Facebook Pharmacy Groups in Jordan. Pharm. Pract. 2020, 18, 1900. [CrossRef] [PubMed]

57. Public Health England. Pharmacy: A Way Forward for Public Health, Opportunities for Action through Pharmacy for Public Health; Public Health England: Londok, UK, 2017; p. 53.

58. WHO. W.H.O. Coronavirus Disease (COVID-19)—World Health Organization. Available online: https://www.who.int/ emergencies/diseases/novel-coronavirus-2019 (accessed on 8 August 2021).

59. Daszak, P.; Olival, K.J.; Li, H. A Strategy to Prevent Future Epidemics Similar to the 2019-NCoV Outbreak. Biosaf. Health 2020, 2, 6-8. [CrossRef] [PubMed]

60. Ross, A.G.P.; Crowe, S.M.; Tyndall, M.W. Planning for the Next Global Pandemic. Int. J. Infect. Dis. 2015, 38, 89-94. [CrossRef] [PubMed]

61. Novelli, M.; Gussing Burgess, L.; Jones, A.; Ritchie, B.W. 'No Ebola ... still Doomed'—The Ebola-Induced Tourism Crisis. Ann. Tour. Res. 2018, 70, 76-87. [CrossRef]

62. Saker, L.; Lee, K.; Cannito, B.; Gilmore, A.; Campbell-Lendrum, D. Globalization and Infectious Diseases: A Review of the Linkages; Special Topics No. 3; World Health Organization on Behalf of the Special Programme for research and training in Tropical Diseases -TDR Steering Committee for Social; Economic and Behavioral Research: Geneva, Switzerland, $2004 ;$ p. 67.

63. Ayeh, J.K.; Leung, D.; Au, N.; Law, R. Perceptions and Strategies of Hospitality and Tourism Practitioners on Social Media: An Exploratory Study. In Proceedings of the Information and Communication Technologies in Tourism 2012, Helsingborg, Sweden, 25-27 January 2012; Fuchs, M., Ricci, F., Cantoni, L., Eds.; Springer: Vienna, Austria, 2012; pp. 1-12.

64. Granville, F.; Mehta, A.; Pike, S. Destinations, Disasters and Public Relations: Stakeholder Engagement in Multi-Phase Disaster Management. J. Hosp. Tour. Manag. 2016, 28, 73-79. [CrossRef]

65. Radic, A.; Lück, M.; Al-Ansi, A.; Chua, B.-L.; Seeler, S.; Han, H. Cruise Ship Dining Experiencescape: The Perspective of Female Cruise Travelers in the Midst of the COVID-19 Pandemic. Int. J. Hosp. Manag. 2021, 95, 102923. [CrossRef] 
66. Malterud, K.; Siersma, V.D.; Guassora, A.D. Sample Size in Qualitative Interview Studies: Guided by Information Power. Qual. Health Res. 2016, 26, 1753-1760. [CrossRef]

67. Jiang, Y.; Ritchie, B.W. Disaster Collaboration in Tourism: Motives, Impediments and Success Factors. J. Hosp. Tour. Manag. 2017, 31, 70-82. [CrossRef]

68. Bryant, A.; Charmaz, K. The SAGE Handbook of Grounded Theory; SAGE: Thousand Oaks, CA, USA, 2007; ISBN 978-1-4462-7572-6.

69. Glaser, B.G.; Strauss, A.L. The Discovery of Grounded Theory: Strategies for Qualitative Research; 4 . paperback printing; Aldine Publishing: New Brunswick, NJ, USA, 2009; ISBN 978-0-202-30260-7.

70. Lai, I.K.W.; Wong, J.W.C. Comparing Crisis Management Practices in the Hotel Industry between Initial and Pandemic Stages of COVID-19. Int. J. Contemp. Hosp. Manag. 2020, 32, 3135-3156. [CrossRef]

71. Cioccio, L.; Michael, E.J. Hazard or Disaster: Tourism Management for the Inevitable in Northeast Victoria. Tour. Manag. 2007, 28, 1-11. [CrossRef]

72. Fyall, A.; Garrod, B.; Wang, Y. Destination Collaboration: A Critical Review of Theoretical Approaches to a Multi-Dimensional Phenomenon. J. Destin. Mark. Manag. 2012, 1, 10-26. [CrossRef]

73. Holmes, E.A.; O'Connor, R.C.; Perry, V.H.; Tracey, I.; Wessely, S.; Arseneault, L.; Ballard, C.; Christensen, H.; Silver, R.C.; Everall, I.; et al. Multidisciplinary Research Priorities for the COVID-19 Pandemic: A Call for Action for Mental Health Science. Lancet Psychiatry 2020, 7, 547-560. [CrossRef]

74. Jamal, T.B.; Getz, D. Collaboration Theory and Community Tourism Planning. Ann. Tour. Res. 1995, 22, 186-204. [CrossRef]

75. Graci, S. Collaboration and Partnership Development for Sustainable Tourism. Tour. Geogr. 2013, 15, 25-42. [CrossRef]

76. Scarpino, M.R.; Gretzel, U. Conceptualizing Organizational Resilience in Tourism Crisis Management. Tour. Crisis Disaster Manag. Asia-Pac. 2014, 1, 15.

77. Ansell, C.; Gash, A. Collaborative Platforms as a Governance Strategy. J. Public Adm. Res. Theory 2018, 28, 16-32. [CrossRef]

78. Kumar, G.; Nath Banerjee, R. Collaboration in Supply Chain: An Assessment of Hierarchical Model Using Partial Least Squares (PLS). Int. J. Product. Perform. Manag. 2012, 61, 897-918. [CrossRef]

79. Ritchie, B.W. Chaos, Crises and Disasters: A Strategic Approach to Crisis Management in the Tourism Industry. Tour. Manag. 2004, 25, 669-683. [CrossRef]

80. Jamal, T.; Stronza, A. Collaboration Theory and Tourism Practice in Protected Areas: Stakeholders, Structuring and Sustainability. J. Sustain. Tour. 2009, 17, 169-189. [CrossRef]

81. Bullock, R.; Armitage, D.; Mitchell, B. Shadow Networks, Social Learning, and Collaborating through Crisis: In Collaborative Resilience, Moving Through Crisis to Opportunity; Goldstein, B.E., Ed.; The MIT Press: Cambridge, MA, USA, 2012; pp. 309-338, ISBN 978-0-262-51645-7.

82. Goldstein, B.E. Collaborative Resilience: Moving Through Crisis to Opportunity; The MIT Press: Cambridge, MA, USA, 2012; ISBN 978-0-262-51645-7.

83. Al-Quteimat, O.M.; Amer, A.M. SARS-CoV-2 Outbreak: How Can Pharmacists Help? Res. Soc. Adm. Pharm. RSAP 2021, 17, 480-482. [CrossRef]

84. American Pharmacists Association Advocacy Issues. Available online: https://pharmacist.com/Advocacy/Issues (accessed on 28 April 2021).

85. Bregoli, I.; Del Chiappa, G. Coordinating Relationships Among Destination Stakeholders: Evidence from Edinburgh (UK). Tour. Anal. 2013, 18, 145-155. [CrossRef]

86. Hartman, S. Resilient Tourism Destinations? Governance Implications of Bringing Theories of Resilience and Adaptive Capacity to Tourism Practice; Routledge: Oxfordshire, UK, 2018; pp. 66-76. ISBN 978-0-203-70190-4.

87. Johnson, R.; McGowan, M.; Turner, L. Grounded Theory in Practice: Is It Inherently a Mixed Method? Psychol. Sch. 2010, 13, 65-78.

88. Elbeddini, A.; Prabaharan, T.; Almasalkhi, S.; Tran, C. Pharmacists and COVID-19. J. Pharm. Policy Pract. 2020, 13, 36. [CrossRef] [PubMed]

89. Liu, S.; Luo, P.; Tang, M.; Hu, Q.; Polidoro, J.P.; Sun, S.; Gong, Z. Providing Pharmacy Services during the Coronavirus Pandemic. Int. J. Clin. Pharm. 2020, 42, 299-304. [CrossRef]

90. Hansson, S.; Orru, K.; Torpan, S.; Bäck, A.; Kazemekaityte, A.; Meyer, S.F.; Ludvigsen, J.; Savadori, L.; Galvagni, A.; Pigrée, A COVID-19 Information Disorder: Six Types of Harmful Information during the Pandemic in Europe. J. Risk Res. 2021, $24,1-14$. [CrossRef]

91. Gao, Y.; Cai, G.-Y.; Fang, W.; Li, H.-Y.; Wang, S.-Y.; Chen, L.; Yu, Y.; Liu, D.; Xu, S.; Cui, P.-F.; et al. Machine Learning Based Early Warning System Enables Accurate Mortality Risk Prediction for COVID-19. Nat. Commun. 2020, 11, 5033. [CrossRef]

92. Campiranon, K.; Scott, N. Critical Success Factors for Crisis Recovery Management: A Case Study of Phuket Hotels. J. Travel Tour. Mark. 2014, 31, 313-326. [CrossRef]

93. Mahase, E. COVID-19: "Mix and Match" Primary Vaccines Are Safe and Effective, Study Finds. BMJ 2021, 375, n3030. [CrossRef]

94. Zheng, S.; Yang, L.; Zhou, P.; Li, H.; Liu, F.; Zhao, R. Recommendations and Guidance for Providing Pharmaceutical Care Services during COVID-19 Pandemic: A China Perspective. Res. Soc. Adm. Pharm. 2021, 17, 1819-1824. [CrossRef]

95. Indar, L.; Hospedales, C.J.; Asin-Oostburg, V. Developing Policy to Support Novel Caribbean Tourism and Health Surveillance Program. Online J. Public Health Inform. 2018, 10, e72. [CrossRef] 
96. Haider, N.; Yavlinsky, A.; Simons, D.; Osman, A.Y.; Ntoumi, F.; Zumla, A.; Kock, R. Passengers' Destinations from China: Low Risk of Novel Coronavirus (2019-NCoV) Transmission into Africa and South America. Epidemiol. Infect. 2020, 148, e41. [CrossRef] [PubMed]

97. International Pharmaceutical Federation COVID-19 Hub. Available online: https://www.fip.org// coronavirus (accessed on 15 December 2021).

98. UNWTO. COVID-19 Tourism Recovery Techincal Assistance Package. Available online: https://www.unwto.org/tourism-covid19 (accessed on 13 January 2022).

99. Blackman, D.; Kennedy, M.; Ritchie, B. Knowledge Management: The Missing Link in DMO Crisis Management? Curr. Issues Tour. 2011, 14, 337-354. [CrossRef] 